\title{
STUDY OF GENE ACTION FOR RESTORER LINES IN SUNFLOWER
}

\author{
Dudhe, M.Y., Moon, M.K. and Lande, S.S.
}

Oilseeds Research Unit, Dr. PDKV, Akola 444001, Maharashtra, India

Received: March 23, 2010

Accepted: August 10, 2010

\begin{abstract}
SUMMARY
Five best sunflower restorer (BR) lines and five elite restorer (ER) lines which were crossed in all possible combinations with half diallel fashion to determine the combining ability, mode of gene action and to quantify the magnitude of heterosis at Oilseeds Research Unit, Dr. PDKV, Akola Maharashtra (India). The ratio of $\sigma^{2} \mathrm{GCA} / \sigma^{2} \mathrm{SCA}$ variances was less than unity for plant height, head diameter, filled seeds/head, 100 seed weight, harvest index, oil content and yield/plant indicating non-additive type of gene actions were involved in these traits. The character, days to maturity was governed by preponderance of additive gene action due to variance ratio observed more than unity. The characters days to maturity, head diameter and 100 seed weight showed the predictability ratio nearer to unity indicating greater predictability based on general combining ability alone. Six crosses $270 \mathrm{R} \times$ Ak-1R, 272R $\times$ $273 \mathrm{R}, 273 \mathrm{R} \times 274 \mathrm{R}, 586 \mathrm{R} \times 857 \mathrm{R}, 265 \mathrm{R} \times \mathrm{Ak}-1 \mathrm{R}$ and $265 \mathrm{R} \times 586 \mathrm{R}$ appeared to be worth exploiting. These promising $R \times R$ crosses can be used for the development of new $\mathrm{R}$ lines in sunflower. It is recommended that in order to get new restorer combinations it is necessary to have at least one elite restorer in combination with best restorer to be incorporated in the breeding programme and vice- versa at least in sunflower.
\end{abstract}

Key wards: gene action, best and elite restorer lines, combining ability, sunflower

\section{INTRODUCTION}

Information on heterosis in sunflower (Helianthus annuus L.) is essential for developing new hybrids. The two important prerequisites exploiting new cms systems in hybrid breeding are availability of stable male sterility and restorer lines. The development of new restorer lines by conventional breeding requires repeated backcrossing of the restorer lines with the recurrent parent, followed by selection of the fertile plants, which is extremely laborious and time consuming due to identification of plants in the backcross progenies that carry genes for restoration. The ideal method to develop new restorer line ( $\mathrm{R}$ line) is by crossing $\mathrm{R} \times \mathrm{R}$ lines from restorer gene pools, which are already identified for fertility restoration in sun- 
flower (Dudhe et al., 2009). Combining ability analysis provides information on the nature and magnitude of gene effects on yield and yield attributing characters. This analysis helps in identification of the potential parents and superior cross combinations and also assist in the formulation of a suitable time bound effective breeding program for the genetic enhancement of yield and yield components. The usefulness of a particular cross in exploiting heterosis is judged by the specific combining ability (SCA) effect. Diallel analysis of restorer lines (R lines) can help to identify and develop new $\mathrm{R}$ lines which later can be used in sunflower hybrid development programs. Hence, the present investigation was planned to identify best $R \times R$ crosses from already identified best restores along with elite restorers from the maintained restorer gene pool by using half diallel method in sunflower.

\section{MATERIALS AND METHODS}

The material included five best sunflower restorer (BR) lines viz., RHA 272, 274, 857, 859 and Ak-1R from which commercial hybrids were already released in India (Table 1) and five elite restorers (ER) RHA 265, 270, 273, 278 and 586. These restorers were crossed manually during the summer of 2005 by hand emasculation and pollination in all possible combinations in half diallel fashion (excluding reciprocals), so that every BR got crossed with every BR, ER and ER with every ER. In Kharif 2006, the 45 hybrids and 10 parents were grown in a randomized block design with three replications with 3 rows, each $2.4 \mathrm{~m}$ in length. The data were collected on yield associated traits like days to maturity, plant height, head diameter, filled seeds/head, 100 seed weight, harvest index, oil content and seed yield/plant. The analysis of variance was computed as per Panse and Sukhatme (1954), for all the characters. Combining ability analysis was carried out by using method II model 1 of Griffing (1956), to study the gene action operating in the inheritance of the characters studied and the predictability ratio was calculated as per Baker (1978), to calculate the progeny performance.

Table 1: Hybrids released for cultivation in India with pedigree, year of release, adaptation zone and few yield contributing traits

\begin{tabular}{|c|c|c|c|c|c|c|}
\hline \multirow{2}{*}{ Hybrid } & \multirow{2}{*}{ Pedigree } & \multirow{2}{*}{$\begin{array}{l}\text { Year of } \\
\text { release }\end{array}$} & \multicolumn{3}{|c|}{ Seed yield Duration Oil content } & \multirow{2}{*}{ Adaptation zone } \\
\hline & & & $\mathrm{kg} / \mathrm{ha}$ & days & $\%$ & \\
\hline $\mathrm{BSH}-1$ & CMS 234A $\times$ RHA 274 & 1980 & $1000-1400$ & $85-90$ & $40-42$ & All India \\
\hline-27 & $\mathrm{CMS}$ & 6 & 00 & $85-90$ & $40-$ & $\begin{array}{c}\text { Vidharbha region o } \\
\text { Maharashtra }\end{array}$ \\
\hline DSH-1 & DSF-15A $\times$ RHA 857 & 1997 & $1200-1400$ & $85-88$ & $41-44$ & Northern Karnataka \\
\hline TCSH-1 & CMS 234A $\times$ RHA 272 & 2000 & $1200-1500$ & $85-90$ & $40-44$ & Tamil Nadu \\
\hline $\begin{array}{l}\text { NDSH-1 } \\
\text { (NDSH 15) }\end{array}$ & CMS $234 \mathrm{~A} \times 8$ & 2003 & 1200 & $88-90$ & $40-42$ & Andhra Pradesh \\
\hline
\end{tabular}




\section{RESULTS AND DISCUSSION}

Mean square values showed that significant differences were observed among mean values for all the yield associated traits except for harvest index. The characters which showed significant differences were days to maturity, plant height, head diameter, filled seeds/head, 100 seed weight, oil content and seed yield in sunflower.

The estimates of general and specific combining ability for parents and specific combining ability effects of crosses are presented in Table 2 . The mean squares due to GCA and SCA were significant for all characteristics under study except harvest index indicating substantial genetic variation for the characters. The ratio of $\sigma^{2}$ $\mathrm{GCA} / \sigma^{2}$ SCA variances was less than unity for plant height, head diameter, filled seeds/head, 100 seed weight, harvest index, oil content and yield/plant which indicated that non-additive type of gene action was primarily involved in the expressions of these traits. The character, days to maturity were governed by preponderance of additive gene action due to variance ratio observed more than unity. However, gene action assessed from combining ability analysis (Griffing, 1956) is not true indication and may not give proper idea regarding gene actions. Therefore, predictability ratio (GCA vs. SCA) was calculated as per Baker (1978), to calculate the progeny performance. The character, days to maturity, head diameter and 100 seed weight showed the predictability ratio nearer to unity indicating greater predictability based on general combining ability alone. Pande (2002) reported non-additive gene action for almost all traits except head diameter. Earlier, Goksoy (2000), reported non-additive gene action for plant height, head diameter and for yield/plant which are in agreement with the present findings.

Table 2: Analysis of variance for combining ability in $10 \times 10$ diallel set

\begin{tabular}{|c|c|c|c|c|c|c|c|c|c|}
\hline \multirow{2}{*}{$\begin{array}{l}\text { Source of } \\
\text { variation }\end{array}$} & \multirow[b]{2}{*}{ DF } & \multicolumn{8}{|c|}{ Mean squares } \\
\hline & & $\begin{array}{l}\text { Days to } \\
\text { maturity }\end{array}$ & $\begin{array}{l}\text { Plant } \\
\text { height }\end{array}$ & $\begin{array}{c}\text { Head } \\
\text { diameter }\end{array}$ & $\begin{array}{c}\text { Filled seeds/ } \\
\text { head }\end{array}$ & $\begin{array}{c}100 \text { seed } \\
\text { weight }\end{array}$ & $\begin{array}{l}\text { Harvest } \\
\text { index }\end{array}$ & $\begin{array}{c}\text { Oil } \\
\text { content }\end{array}$ & $\begin{array}{l}\text { Yield/ } \\
\text { plant }\end{array}$ \\
\hline GCA & 9 & $7.561^{\star \star}$ & $310.221^{* *}$ & $20.009 \star \star$ & $704.882^{\star \star}$ & $6.313^{\star \star}$ & 2.404 & $14.459 * \star$ & 19.064 ** \\
\hline SCA & 45 & 1.249 & $123.785^{\star * *}$ & $3.227^{\star \star}$ & $414.260 * *$ & $0.909 * *$ & 1.438 & $10.025^{\star *}$ & $8.868^{\star *}$ \\
\hline Error & 108 & 0.726 & 33.902 & 0.800 & 108.599 & 0.239 & 25.784 & 2.851 & 1.967 \\
\hline \multicolumn{10}{|c|}{ Estimates of genetic components } \\
\hline$\sigma^{2} \mathrm{~g}$ & & 0.569 & 23.026 & 1.600 & 49.690 & 0.516 & -1.948 & 0.967 & 1.424 \\
\hline$\sigma^{2} \mathrm{~s}$ & & 0.523 & 89.883 & 2.426 & 35.661 & 0.669 & -24.346 & 7.174 & 6.907 \\
\hline \multicolumn{2}{|c|}{ Ms GCA / MSCA } & 6.053 & 2.506 & 6.200 & 1.701 & 6.944 & 1.671 & 1.442 & 2.149 \\
\hline \multicolumn{2}{|c|}{$\sigma^{2} \mathrm{GCA} / \sigma^{2} \mathrm{SCA}$} & 1.087 & 0.256 & 0.659 & 0.162 & 0.756 & 0.080 & 0.134 & 0.206 \\
\hline \multicolumn{2}{|c|}{$\begin{array}{l}\text { GCA vs SCA } \\
\text { (Backer,1978) }\end{array}$} & 0.923 & 0.833 & 0.925 & 0.772 & 0.932 & 0.769 & 0.742 & 0.811 \\
\hline
\end{tabular}

\footnotetext{
*, Significant at $5 \%$; ** Significant at $1 \%$ level of significance
} 
Table 3: Selected $\mathrm{R} \times \mathrm{R}$ crosses showing nature of cross, high per se performance of hybrid, better parent heterosis, GCA and SCA effects of the parents for various characters

\begin{tabular}{|c|c|c|c|c|c|c|c|}
\hline \multirow{2}{*}{$\begin{array}{l}\text { Sr. } \\
\text { No }\end{array}$} & \multirow{2}{*}{$\begin{array}{l}\text { Nature } \\
\text { of cross }\end{array}$} & \multirow{2}{*}{$\begin{array}{l}\text { Characters/ } \\
\text { cross }\end{array}$} & \multirow{2}{*}{$\begin{array}{c}\text { Perse } \\
\text { performance } \\
\text { of hybrid }\end{array}$} & \multirow{2}{*}{$\begin{array}{c}\text { BP } \\
\text { Heterosis }\end{array}$} & \multicolumn{2}{|c|}{ GCA effects of parents } & \multirow{2}{*}{$\begin{array}{c}\text { SCA effects } \\
\text { of parents }\end{array}$} \\
\hline & & & & & P1 & P2 & \\
\hline \multicolumn{8}{|c|}{ Days to maturity } \\
\hline 1 & $\mathrm{ER} \times \mathrm{BR}$ & $270 \mathrm{R} \times \mathrm{AK}-1 \mathrm{R}$ & 76.00 & $-3.80 * \star$ & $-1.29^{\star \star}(H)$ & $-0.82^{\star \star}(\mathrm{H})$ & $-2.67^{\star \star}$ \\
\hline 2 & $\mathrm{ER} \times \mathrm{BR}$ & $270 R \times 272 R$ & 77.67 & -1.69 & $-1.29 * *(H)$ & $-0.90^{\star *}(\mathrm{H})$ & -1.09 \\
\hline 3 & $\mathrm{ER} \times \mathrm{BR}$ & $270 \mathrm{R} \times 859 \mathrm{R}$ & 79.00 & 0.00 & $-1.29^{\star \star}(H)$ & $0.93^{\star \star}(\mathrm{H})$ & -1.51 \\
\hline \multicolumn{8}{|c|}{ Head Diameter } \\
\hline 1 & $\mathrm{ER} \times \mathrm{ER}$ & $273 R \times 278 R$ & 15.53 & $43.83^{\star \star}$ & $1.70^{\star \star}(\mathrm{H})$ & $1.27(\mathrm{H})$ & 1.35 \\
\hline 2 & $\mathrm{ER} \times \mathrm{ER}$ & $272 R \times 273 R$ & 14.80 & $37.89 \star \star$ & $-1.63^{\star}(\mathrm{L})$ & $1.78^{\star \star}(H)$ & $3.51 * *$ \\
\hline 3 & $\mathrm{ER} \times \mathrm{BR}$ & $273 R \times 274 R$ & 14.47 & $34.78^{\star *}$ & $1.70 * \star(H)$ & $-0.80 *(\mathrm{~L})$ & $2.35^{\star \star}$ \\
\hline 4 & $\mathrm{ER} \times \mathrm{ER}$ & $278 \mathrm{R} \times 578 \mathrm{R}$ & 14.13 & $26.57^{\star \star}$ & $1.15^{\star \star}(\mathrm{H})$ & $1.15(\mathrm{H})$ & 0.50 \\
\hline \multicolumn{8}{|c|}{ Plant height } \\
\hline 1 & $\mathrm{ER} \times \mathrm{BR}$ & $270 \mathrm{R} \times 272 \mathrm{R}$ & 77.33 & 1.75 & $-6.88^{* *}(H)$ & $-7.09 * *(\mathrm{H})$ & -7.27 \\
\hline 2 & $\mathrm{~EB} \times \mathrm{ER}$ & $272 \mathrm{R} \times 586 \mathrm{R}$ & 78.67 & -7.81 & $-7.09^{* *}(H)$ & $0.29(\mathrm{~L})$ & -13.10 \\
\hline 3 & $\mathrm{ER} \times \mathrm{BR}$ & $270 \mathrm{R} \times \mathrm{Ak}-1 \mathrm{R}$ & 88.67 & 6.78 & $-7.09^{\star \star}(H)$ & $-0.86(L)$ & -2.16 \\
\hline \multicolumn{8}{|c|}{ Filled seeds/Head } \\
\hline 1 & $\mathrm{ER} \times \mathrm{ER}$ & $270 \mathrm{R} \times 278 \mathrm{R}$ & 88.43 & 13.62 & $13.46^{\star \star}(\mathrm{H})$ & $1.88(\mathrm{~L})$ & 14.84 \\
\hline 2 & $\mathrm{ER} \times \mathrm{BR}$ & $586 \mathrm{R} \times \mathrm{Ak}-1 \mathrm{R}$ & 84.64 & $-60.16^{\star \star}$ & $4.36(\mathrm{~L})$ & $-4.07(\mathrm{~L})$ & $28.45^{\star \star}$ \\
\hline 3 & $\mathrm{BR} \times \mathrm{BR}$ & $272 \mathrm{R} \times \mathrm{Ak}-1 \mathrm{R}$ & 84.19 & -1.14 & $-7.30(\mathrm{~L})$ & $-4.07(L)$ & $31.61 * \star$ \\
\hline \multicolumn{8}{|c|}{100 Seed weight } \\
\hline 1 & $\mathrm{ER} \times \mathrm{ER}$ & $273 R \times 278 R$ & 6.37 & $43.61^{* \star}$ & $1.15(L)$ & $0.57(\mathrm{~L})$ & 3.10 \\
\hline 2 & $\mathrm{BR} \times \mathrm{ER}$ & $274 \mathrm{R} \times 278 \mathrm{R}$ & 6.20 & $93.75^{\star *}$ & $-0.50(\mathrm{~L})$ & $0.57(\mathrm{~L})$ & $-24.74^{\star *}$ \\
\hline 3 & $\mathrm{ER} \times \mathrm{ER}$ & $265 R \times 273 R$ & 6.10 & $37.59 * *$ & $0.78(\mathrm{~L})$ & $1.15(\mathrm{~L})$ & -0.55 \\
\hline 4 & $\mathrm{ER} \times \mathrm{ER}$ & $265 R \times 278 R$ & 6.03 & $40.31 * *$ & $0.78(\mathrm{~L})$ & $0.57(\mathrm{~L})$ & 17.96 \\
\hline \multicolumn{8}{|c|}{ Harvest index } \\
\hline 1 & $\mathrm{BR} \times \mathrm{ER}$ & $272 R \times 273 R$ & 0.49 & $206.25^{\star *}$ & $-4.60(\mathrm{~L})$ & $5.00(\mathrm{~L})$ & 0.25 \\
\hline 2 & $\mathrm{ER} \times \mathrm{ER}$ & $270 \mathrm{R} \times 278 \mathrm{R}$ & 0.48 & $317.65^{\star \star}$ & $1.00(\mathrm{~L})$ & $2.00(\mathrm{~L})$ & 0.21 \\
\hline 3 & $\mathrm{ER} \times \mathrm{BR}$ & $265 R \times A k-1 R$ & 0.48 & $107.14^{\star \star}$ & $8.00(\mathrm{H})$ & $-1.00(L)$ & 0.17 \\
\hline 4 & $\mathrm{ER} \times \mathrm{BR}$ & $265 \mathrm{R} \times 274 \mathrm{R}$ & 0.46 & 110.61 ** & $8.50(\mathrm{H})$ & $-5.00(L)$ & 0.20 \\
\hline \multicolumn{8}{|c|}{ Oil content } \\
\hline 1 & $\mathrm{ER} \times \mathrm{BR}$ & $586 \mathrm{R} \times 857 \mathrm{R}$ & 39.38 & $27.16^{\star *}$ & $1.48^{*}(H)$ & $1.10(\mathrm{~L})$ & $5.27^{\star \star}$ \\
\hline 2 & $\mathrm{ER} \times \mathrm{BR}$ & $586 \mathrm{R} \times \mathrm{Ak}-1 \mathrm{R}$ & 36.53 & 3.12 & $1.48^{*}(H)$ & $0.61(\mathrm{~L})$ & -1.68 \\
\hline 3 & $\mathrm{BR} \times \mathrm{ER}$ & $274 \mathrm{R} \times 586 \mathrm{R}$ & 36.41 & 13.90 ** & $0.80(\mathrm{~L})$ & $1.48^{* *}(H)$ & 2.60 \\
\hline 4 & $\mathrm{ER} \times \mathrm{ER}$ & $265 \mathrm{R} \times 278 \mathrm{R}$ & 36.32 & $24.48^{\star \star}$ & $0.73(\mathrm{~L})$ & $-1.46^{*}(\mathrm{~L})$ & $5.52^{* \star}$ \\
\hline \multicolumn{8}{|c|}{ Yield/plant } \\
\hline 1 & $\mathrm{ER} \times \mathrm{BR}$ & $586 \mathrm{R} \times 857 \mathrm{R}$ & 13.29 & $110.26^{\star \star}$ & 0.67 (L) & $-0.54(L)$ & $6.23^{\star *}$ \\
\hline 2 & $\mathrm{ER} \times \mathrm{BR}$ & $265 R \times A k-1 R$ & 12.91 & $152.87^{\star \star}$ & $1.79 * \star(H)$ & $0.67(\mathrm{~L})$ & $3.86^{\star \star}$ \\
\hline 3 & $\mathrm{ER} \times \mathrm{ER}$ & $265 R \times 586 R$ & 12.61 & $147.00^{\star *}$ & $1.79 * *(H)$ & $0.67(\mathrm{~L})$ & $3.22^{\star *}$ \\
\hline 4 & $\mathrm{ER} \times \mathrm{ER}$ & $270 R \times 278 R$ & 12.08 & $174.55^{\star \star}$ & $-0.44(L)$ & $0.81(\mathrm{~L})$ & $4.77^{\star \star}$ \\
\hline
\end{tabular}

$\mathrm{BR} / \mathrm{ER}=$ Best/Elite Restorers, $\mathrm{H}=$ High, $\mathrm{L}=$ Poor

*, Significant at $5 \% ;{ }^{* \star}$ Significant at $1 \%$ level of significance 
Selected $\mathrm{R} \times \mathrm{R}$ crosses showing nature of cross, high per se performance of hybrid, better parent heterosis, GCA and SCA effects of the parents for various characteristics are shown in Table 3. As the performance of $F_{1}$ hybrids over better parent was significant, the heterosis over better parent has been considered for discussion (Dudhe et al., 2009). The highest positive better parent heterosis was observed for harvest index in the crosses $270 \mathrm{R} \times 278 \mathrm{R}$, which was significantly highest among all the characters studied. For seed yield per plant the same cross recorded highest better parent heterosis and for oil content cross $586 \mathrm{R} \times 857 \mathrm{R}$ recorded highest better parent heterosis along with high mean. The high $\times$ high crosses with best GCA effects and high mean performance were observed for days to maturity $(270 \mathrm{R} \times \mathrm{AK}-1 \mathrm{R})$, head diameter $(273 \mathrm{R} \times 278 \mathrm{R})$ and plant height $(270 \mathrm{R}$ $\times 272 \mathrm{R}$ ) indicating that additive $\mathrm{x}$ additive effects are fixable component and single plant selection would be desirable in segregating generations at least for these characters. One cross for head diameter and for oil content showed low $\times$ high GCA effects along with high mean and significant better parent heterosis. Whereas low $\times$ low GCA effects along with high mean was recorded in eleven cross combinations for filled seed/head, 100 seed weight, harvest index, oil content and yield/plant. In the present study, low $\times$ low GCA combination also produced hybrids with high SCA and this could be attributed to over-dominance or epistatic gene action. All these results revealed that there is no direct relation between GCA effects of the parents and SCA effects of the hybrid combinations. This could be explained from the point of view of gene action since GCA is mostly due to additive gene action whereas SCA is mostly due to over-dominance and epistasis. Cross $586 \mathrm{R} \times 857 \mathrm{R}$ is best for yield per plant and oil content is due to low $\times$ low for yield/plant and high $\times$ low GCA effect for oil content along with high mean which is rare combination. An ideal combination to be exploited is one where high degree of SCA is present in addition to high GCA of both or at least in one parent along with high better parent heterosis. Six crosses $270 \mathrm{R} \times \mathrm{Ak}-1 \mathrm{R}, 272 \mathrm{R} \times 273 \mathrm{R}, 273 \mathrm{R} \times 274 \mathrm{R}, 586 \mathrm{R} \times 857 \mathrm{R}, 265 \mathrm{R} \times$ Ak-1R and $265 \mathrm{R} \times 586 \mathrm{R}$ appear to be worth exploiting. The present results are in the agreement of Pande (2002) and Goksoy et al., (2000) as they also reported crosses having high SCA effects with the parents of either high $\times$ high, high $\times$ low or low $\times$ low GCA effects.

The parent $270 \mathrm{R}$ (elite restorer) were good general combiners for seed yield along with yield-contributing characters like harvest index, filled seeds/head, plant height and for days to maturity. Parent 265R (elite restorer) was good combiner for oil content, harvest index, 100 seed weight and yield per plant. The parent Ak-1R (best restorer) was good general combiner for yield/plant, oil content, harvest index, plant height and days to maturity. Out of twenty nine crosses presented in Table 2 only one $\mathrm{BR} \times \mathrm{BR}$ cross combination $(272 \mathrm{R} \times \mathrm{Ak}-1 \mathrm{R})$ was observed for character filled seeds per head it indicates that the frequency of getting bet restorer combination by crossing $\mathrm{BR} \times \mathrm{BR}$ is less. Eleven cross combinations were observed for $\mathrm{ER}$ $\times \mathrm{ER}$ and seventeen crosses are either $\mathrm{ER} \times \mathrm{BR}$ or $\mathrm{BR} \times \mathrm{ER}$ combinations which 
show better complementation between favourable alleles in elite restorers and elite and better restorers. Hence, it is concluded that in order to get new restorer combinations it is necessary to have at least one elite restorer in combination with best restorer to be incorporated in the breeding programme and vice- versa. Also, these restorer combinations can be seen as new potent restorer lines because the fertility restoration genes are accumulated in these crosses and can be used for the development of new "R" lines in sunflower.

\section{CONCLUSION}

Six crosses $270 \mathrm{R} \times \mathrm{Ak}-1 \mathrm{R}, 272 \mathrm{R} \times 273 \mathrm{R}, 273 \mathrm{R} \times 274 \mathrm{R}, 586 \mathrm{R} \times 857 \mathrm{R}, 265 \mathrm{R}$ $\times$ Ak-1R and $265 \mathrm{R} \times 586 \mathrm{R}$ identified with high degree of SCA in addition to high GCA of both or at least in one parent along with high better parent heterosis, these promising $\mathrm{R} \times \mathrm{R}$ crosses can be used for the development of new $\mathrm{R}$ lines in sunflower. It is also suggested that simple recurrent selection or bi-parental mating followed by reciprocal recurrent selection among the crosses having desirable yield components may be effective in genetic amelioration of the characters under study. The parent $270 \mathrm{R}, 265 \mathrm{R}$ and Ak-1R were good general combiners for yield and yield attributing traits and can be used in synthetic breeding programme. Also from above findings it is recommended that it is better to incorporate more and higher number of $\mathrm{ER} \times \mathrm{ER}$ and $\mathrm{ER} \times \mathrm{BR}$ or $\mathrm{BR} \times \mathrm{ER}$ crosses for the development of new restorer lines, at least in sunflower. The new information generated through this research of specific effects of elite restorers and best restorers on yield traits, which was hitherto lacking, has significant bearing on the development of new restorer lines in sunflower breeding aimed towards the improvement of yield traits. The results will guide the breeders as regards the choice of restorers for developing new restorer lines in sunflower.

\section{REFERENCES}

Baker, R.J., 1978. Issues in diallel analysis. Crop Sci. 18(4): 533-536.

Dudhe, M.Y., Moon, M.K. and Lande, S.S., 2009. Evaluation of restorer lines for heterosis studies on sunflower. J. Oilseeds Res. 26 (Special issue):140-142.

Goksoy, A.T., Turkec, A.T. and Turan, Z.M., 2000. Heterosis and combining ability in sunflower. (Helianthus annuus L.). Indian J. Agric. Sci. 70(8): 525-529.

Griffing, B., 1956. Concepts of general and specific combining ability in relation to diallel crossing systems. Aust. J. Biol. Sci. 9: 463-493.

Pande, M.K., 2002. Variance analysis and graphical approach for study of gene action in sunflower. Ph.D Thesis (unpb) Dr. PDKV, Akola.

Panse, V.G. and Sukhatme, P.V., 1954. Statistical methods for Agricultural Workers. Indian Council of Agril. Res., New Delhi. 